\title{
Paremiološka građa hercegovačke hrvatske periodike na prijelazu iz 19. u 20. stoljeće
}

IRINA BUDIMIR

Sveučilišta u Mostaru

Filozofski fakultet

E-pošta: irina.budimir@ff.sum.ba
UDK: 070(497.6 Hercegovina)"18"/"19"

81 '37

Izvorni znanstveni rad

Primljeno: 28. veljače 2020.

Prihvaćeno: 10. lipnja 2020.

\section{Sažetak}

U radu će se prikazati paremiološka građa hercegovačke hrvatske periodike na prijelazu iz 19. u 20. stoljeće. Tiskovine toga doba obiluju stranim i domaćim paremiološkim vrstama. Poseban će se naglasak dati strukturnoj i semantičkoj raščlambi hrvatske paremije. Pojava paremije u novinarsko-publicističkom funkcionalnome stilu i njegovim različitim rodovima (vijest, osvrt, komentar, podlistak i sl.) toga vremena ogleda se u njezinoj važnosti uporabe i za autore tekstova i za čitalačku publiku jer predstavlja izraz uvjerenja, vrijednosti i norme povezane s kulturom i važećim socijalnim vrijednostima. Brojnost njihova objavljivanja u tadašnjim tiskovinama dokumentiran je dio ne samo usmenoga narodnog blaga jednoga vremenskog odsječka, nego i posebnosti onodobna novinarsko-publicističkoga funkcionalnog stila koji čuva kulturno, jezično i komunikacijsko nasljeđe naroda.

Ključne riječi: paremija; novinarsko-publicistički funkcionalni stil; starija hercegovačka hrvatska periodika; strukturna i semantička raščlamba. 
Irina Budimir - Paremiološka građa hercegovačke hrvatske periodike...

\section{Uvod}

Paremije (poslovice ${ }^{1}$ ) nisu samo dio usmenoga narodnog blaga iz kojega potječu, nego se već stoljećima bilježe u raznim pisanim izvorima, u različitim oblicima i opsezima iz čega se "može promotriti poetika, tematika, estetika, izvedba i receptivnost". ${ }^{2}$ Isto tako paremije predstavljaju "vrlo važan dio raznovrsnih govornih čina, kako zbog njihove sažetosti i kratkoće, tako i zbog njihove dojmljivosti, poučnosti i višenamjenske upotrebljivosti". ${ }^{3}$ Paremiološka obilježja su: "čestotnost uporabe, specifična sintaktička struktura, metaforičnost, sažetost, dobar izbor riječi i dr." ${ }^{14}$ Šara $^{5}$ uz ta obilježja navodi još nekoliko njih kao što su: "tradicionalni karakter, poučnost, ustaljena forma", a kao obilježja mogu se istaknuti i "anonimnost autora, značenje izvan konteksta, poznate su većem broju govornika i iznose neko životno iskustvo". ${ }^{6}$

Paremije $^{7}$ "imaju ustaljeni, nepromjenjivi leksički inventar i u većini slučajeva imaju 'metaforično, poopćeno značenje', koje nije identično

1 Naziv poslovica u hrvatski jezik došao je iz ruskoga jezika preko pisma, a kao složenici ili izvedenici u osnovi joj stoji leksem slovo u značenju riječ. Kao takav termin ustalio se u 19. stoljeću. Do tada se poslovica nazivala različito: riječ, prirječje (prirečje, pririč, priričak, proričje i sl.) što je doslovan prijevod latinske riječi proverbium. U starijoj hrvatskoj književnost i leksikografiji koristili su se još latinski nazivi dicteria, adagium, adagia, a služilo se i terminima sentencija, gnoma. Vidi u: JosıP KeKez, Poslovice, zagonetke i govornički oblici, Matica hrvatska, Zagreb, 1996., str. 14-16.

2 Isto, str. 23.

3 Pavao Mikić - Vjekoslav Suzanić, Biblijske poslovice u Hrvata, Školska knjiga - Hrvatski institut za liturgijski pastoral, Zagreb - Zadar, 1994., str. 5.

4 Pavao Mikić - Danica ŠKara, Kontrastivni rječnik poslovica, Školska knjiga, Zagreb, 1992., str. VIII.

5 Danica Škara, Glas tradicije, Ziral, Mostar - Zagreb, 1997., str. 11.

6 P. Mikić - V. Suzanić, Biblijske poslovice u Hrvata, str. 11.

7 U ovom će se radu koristiti termin paremija. Paremije su ekscerptirane iz prvih hrvatskih novina u Hercegovini na prijelazu iz 19. u 20. stoljeće: Hercegovački bosiljak (dalje: HB), Novi hercegovački bosiljak (dalje: NHB) i Glas Hercegovca (dalje: GH). Primjeri su ekscerptiranih paremija u radu obilježeni malim podebljanim slovima u kurzivu. Uza svaku paremiju dana je kratica izvora, godina, broj i stranica. Primjer hrvatske paremije: ni maška kriva, da je gospodarica lina $(\mathrm{GH}, 1885 .: \mathrm{II} / 48 / 2)$. Uz paremije stranoga podrijetla ili druge paremiološke vrste stranoga podrijetla u zagradi je navedeno značenje npr. ad absurdum ('do apsurda') (GH, 1892.: IX/77/2). 
sadržaju koji se neposredno priopćava u rečenici. U njima se skriva 'dublji smisao' koji treba odgonetnuti, a ne može se razaznati iz doslovnoga značenja riječi". ${ }^{8}$ Paremiju treba razlikovati od ostalih sličnih paremioloških vrsta kao što su: "sentencija, krilatica, aforizam, maksima, epigram, slogan, proširena poslovica, poslovična izreka, poslovična usporedba i protuposlovica".

I Kekez navodi podjelu paremioloških vrsta prema tzv. "kompozicijskom načelu"10 dijeleći ih na:

1. jednostavne poslovice (prave i potpune) koje imaju strukturu rečenice i dijele se na: jednodijelne i dvodijelne (tzv. binarna kompozicija)

2. izreke

3. dijaloške poslovice ili poslovice - pitalice

4. poslovice - anegdote ili poslovice - pričice

5. paremiologizme koji se sastoje od: frazeologizma, poredaba, metafora.

U smislu znanstvenoga definiranja i određivanja paremije u okviru istraživanja postoje različita gledišta.

Za neke autore frazeologija u užem smislu proučava isključivo frazeme (idiomatizirane veze leksema), a frazeologija u širem smislu uz frazeme proučava i poslovice, izreke, protuposlovice, velerizme, posuđene poslovice i krilatice. ${ }^{11}$

Fink Arsovski ${ }^{12}$ opisujući frazeološka obilježja kao razliku između dviju vrsta frazeologije, navodi da kod frazeologije u širem smislu "gotovo da i nema desemantizacije, ekspresivnosti i konotativnosti, a slikovitost je znatno rjeđa", što se najviše odnosi na termine i stručno nazivlje.

U novijoj se literaturi paremije definiraju kao "zatvorene rečenice / forme razumljive bez konteksta ili dodatna leksičkog elementa. Ta

8 Wolfgang Fleischer, Phraseologie der deutschen Gegenwartssprache, Max Niemayer Verlag, Tübingen, ${ }^{2}$ 1997., str. 77.

9 P. Mikić - V. Suzanić, Biblijske poslovice u Hrvata, str. 7.

10 J. KeKez, Poslovice, zagonetke i govornički oblici, str. 45-47.

11 Palm Christine, Phraseologie: Eine Einführung, Tübingen, ${ }^{2} 1997 .$, str. 1-6.

12 ŽElJKa Fink Arsovski, Hrvatsko-romansko-germanski rječnik poredbenih frazema, Knjigra, ožujak 2016., Zagreb, str. 5. 
Irina Budimir - Paremiološka građa hercegovačke hrvatske periodike...

formalna karakteristika pod čestim nazivom 'zatvorena forma' je izraz semantičkoga i komunikativnoga obilježja. S obzirom na to da su paremije zatvorene, cjelovite forme, na semantičkoj razini mogu se karakterizirati kao samostalni 'mikrotekstovi'. Iz perspektive govornika: koriste se (kao i ostali frazemi s relativnom stabilnosti) poput samostalnih jedinica bez nužne potrebe za kontekstom, a iz perspektive sugovornika: mogu se razumjeti bez konteksta". ${ }^{13}$ Tako frazeologija proučava paremije na najmanje četiri razine kroz: njihovo značenje, modele (različite stupnjeve apstrakcije) prema kojima se razlikuje nekoliko semantičkih skupina paremija, socijalne i kontekstualne elemente. ${ }^{14}$

Fleischer ${ }^{15}$ paremiju promatra kao povijesno određenu i za razliku od frazema, predstavlja vlastiti mikrotekst koji se ne reproducira kao leksička jedinica, dok Burger, ${ }^{16}$ smještajući paremiju u okvir frazeologije, ističe njezine značajke jer ispunjavaju temeljne uvjete frazema kao što su: polileksičnost, idiomatičnost i u određenom opsegu stabilnost (čvrstoću), dok neke sadrže formalno arhaična svojstva, tj. nepravilne su.

Iz navedenoga je razvidno da se paremija prema svojim obilježjima razlikuje od drugih vrsta frazeologije u širem smislu, ali i od samih frazema. Za nju je u manjem ili većem stupnju svojstvena slikovitost i metaforičnost. Zbog svojih obilježja i semantičke, strukturne i uporabne posebnosti interes je za proučavanje paremije u jeziku uvijek aktualan i mnogim istraživačima zanimljiv i motivirajući.

Uza svoju je funkcionalnu posebnost vrlo pristupačna podloga za uporabu paremije novinarsko-publicistički funkcionalni stil. Pojavnost i tumačenje paremije u tomu stilu bila je tema mnogih suvremenih istraživanja. ${ }^{17}$

13 Herald Burger, Phraseologie, eine Einführung am Beispiel des Deutschen, Erich Schmidt Verlag, Berlin, ${ }^{5} 2015 .$, str. 107.

14 Isto, str. 126.

15 W. FleisCher, Phraseologie der deutschen Gegenwartssprache, str. 77.

16 H. Burger, Phraseologie, eine Einführung am Beispiel des Deutschen, str. 110.

17 Tako poslovice u publicističkom stilu raščlanjuju: Vinko Endstrasser, "Poslovice u novinskom tekstu", u: Narodna umjetnost, vol. 27, No. 1, Zagreb, 1990., str. 141-150; ŽElJKa Matulina, "Paremija u njemačkom i hrvatskom televizijskom programu", u: Fluminensia, god. 17, Rijeka, 2005., br. 2, str. 6784; Draženka Molnar - Dubravka Vidaković Erdeljić, "Paremija u pi- 
Paremija je bila vrlo snažno izražajno sredstvo i u starijem novinarsko-publicističkom stilu u svim ondašnjim novinskim rodovima, a današnju javnu komunikaciju svojom slikovitošću, metaforičnošću i dinamičnošću obogaćuju ne samo tradicionalne, nego "sve prisutnije i modificirane paremije". ${ }^{18}$

\section{Paremija u hercegovačkim hrvatskim novinama na prije- lazu iz 19. u 20. stoljeće}

Još prije pojave hrvatskih novina u Hercegovini, sredinom 19. stoljeća, od 1812. godine hrvatski pokret za jezičnu obnovu sve više jača i ima velik utjecaj na javnu riječ u Hrvatskoj. Tako u "okružnici biskupa M. Vrhovca od 1813. između ostaloga stoji i poziv duhovnim pastirima na prikupljanje izreka, poslovica, narodnih pjesama kao i starinskih knjiga". ${ }^{19}$ Poslanica Maksimilijana Vrhovca kojom se poziva na skupljanje usmeno-književnoga i jezičnoga blaga, kako bi se unaprijedila hrvatska književnost, njezin jezik i kultura tiska se u Gajevoj Danci ilirskoj koja još od prvoga broja redovito objavljuje paremije. ${ }^{20} \mathrm{U}$ to se vrijeme paremije objavljuju u mnogim časopisima, kalendarima. Tako se u Bosanskom prijatelju (u godištima 1850., 1851., 1861., 1870.) objavljuje paremiološko blago iz Bosne i Hercegovine Franje Jukića, a Mehmedbeg Kapetanović Ljubušak zajedno sa suradnicima 1887. u Sarajevu objavljuje prikupljenu paremiološku građu pod naslovom Narodno blago. ${ }^{21}$

$\mathrm{Na}$ temelju te tradicije u prvim hercegovačkim hrvatskim novinama vlada veliko zanimanje za paremiju. Prve novine na hrvatskome jeziku u Hercegovini počinju se objavljivati u tiskari ${ }^{22}$ don Franje Mi-

sanoj javnoj komunikaciji u hrvatskome i engleskome jeziku", u: Jezikoslovlje, 10.1-2, Osijek, 2009., str. 45-58.

18 D. Molnar - D. V. Erdeljić, "Paremija u pisanoj javnoj komunikaciji u hrvatskome i engleskome jeziku", str. 47.

19 István NYOMÁRKAY, Ungarische Vorbilder der kroatischen Spracherneuerung, Budapest, 1989., str. 35.

20 J. Kekez, Poslovice, zagonetke i govornički oblici, str. 21.

21 Isto, str. 23.

22 Do sredine 19. stoljeća postojale su samo četiri tiskare u Bosni i Hercegovini: tiskara u crkvi sv. Georgija (Goražde, 1531.), Vilajetska štamparija (Sarajevo, 1865.), Tiskara vilajeta hercegovačkoga (Mostar, 1876.) i Tiskara katoličkog poslanstva (Mostar, 1872.). O radu Tiskare katoličkoga poslanstva pisano je u mnogim izvorima: Hamdija Kreševljaković, "Štamparije u Bosni i Her- 
Irina Budimir - Paremiološka građa hercegovačke hrvatske periodike...

lićevića. Prva namjera njegove tiskarske djelatnosti bila je novinstvo, međutim čekajući dopuštenja državnih vlasti, ona je bila usmjerena na ostalo izdavaštvo. ${ }^{23}$ Pod njegovim uredništvom i autorstvom ${ }^{24}$ izlaze mnoge knjige, priručnici, kalendari, gramatike i udžbenici. ${ }^{25}$ Svojim predanim radom i angažiranošću u kulturnome, prosvjetiteljskome i novinarskome radu don Franjo Milićević ostavio je neizbrisiv trag u povijesnom, kulturnom nasljeđu Hercegovine. ${ }^{26}$

U razdoblju od 1883. do 1896. izlaze prve hercegovačke novine na hrvatskome jeziku koje se u različitim razdobljima različito nazivaju: Hercegovački bosiljak (HB), Novi hercegovački bosiljak (NHB) i Glas Hercegovca $(\mathrm{GH})^{27}$ s obzirom na vrstu sadržaja kojeg objavljuju od povijesno-književnoga i zabavno-poučnoga do političko-informativnoga.

cegovini za turskog vremena od 1529. do 1878. godine", u: Građa za povijest hrvatsku i književnost, knjiga 9, Sarajevo, 1920.; Fra Leo Petrović, "Prva hrvatska tiskara u BiH", u: Hrvatski narodni kalendar za 1938., Napredak, god. 28, Sarajevo, 1938., str. 57-70; Teodor KrušEvac, BiH listovi u XIX. veku, Veselin Masleša, Sarajevo, 1978.; Fra ANTE Marić, "Tiskare i kulturno-izdavačka djelatnost hercegovačkih franjevaca", u: Hercegovina franciscana, 5, Mostar, 2009., str. 327-352.

23 "Milićević je kanio, da odmah izdaje i list, nu nije dobio za to fermana. Morao se ograničiti na izdavanje školskih knjiga i kalendara te drugih dopuštenih edicija", Ivan A. MilićEvić, "Tiskara don Frane M. Milićevića u Mostaru", u: Glasnik jugoslovenskog profesorskog društva, tematski broj: Mostar i Hercegovina, Beograd, juli - avgust, 1937., str. 1054.

$24 \mathrm{O}$ spisateljskom i prosvjetnom radu autora prvih hrvatskih hercegovačkih listova pisao je Š. Musa dajući popis najvažnijih djela, biografskih i bibliografskih podataka. Vidi u: Šmun Musa, Franjo Milićević $i$ hrvatski kulturni preporod u Hercegovini, Mostar, 1992., str. 45.

25 "Za školstvo i za razvoj pismenosti na spomenutim prostorima od posebne je važnosti pojava početnica, pravopisa i gramatika, a najbrojnije se pripisuju Franji Milićeviću." KatiCa Krešsć, Filološki priručnici i udžbenici za hrvatski jezik u Hercegovini krajem 19. stoljeća, doktorska disertacija, Zagreb, 2009., str. 9.

26 Tadašnji glavni urednik hrvatskoga hercegovačkog lista Osvit (1898.-1907.) Ivan Aziz Milićević, u čast prvome uredniku hercegovačkih novina na hrvatskome jeziku, objavio je veliku autobiografiju don Franje Milićevića u: Osvit, Mostar, 1903., br. 13. O don Franjinu životu i radu pisali su Ivan Alilović, Tragom hrvatske kulturne baštine u Hercegovini, Zagreb, 1980., str. 53-56 i fra Leo Petrović, "Prva hrvatska tiskara u BiH", u: Hrvatski narodni kalendar za 1938, Napredak, god. 28, Sarajevo, 1938., str. 57-70.

27 Izvori za ovaj rad su: Hercegovački bosiljak (HB), 1883./1884., god. I., br. 2, str. 17, 18, 19; br. 3 ili 4, str. 33-40; br. 5, str. 57-60; br. 6, str. 73-80 - povijesno-književni list. Novi hercegovački bosiljak (NHB), 1884., god. I., br. 1-18; god. II, br. 19-37 - list za zabavu, pouku i književnost. Glas Hercegovca (GH), 1885., god. 
Tako se specifičnost novinarskoga stila prvih hercegovačkih novina na hrvatskome jeziku i publicistike ogleda i u uporabi ustaljenih izraza, izreka, metaforičkih izričaja i ustaljenih - frazeologiziranih konstrukcija.

$\mathrm{Na}$ uporabu paremije utjecali su folklorni i kulturno-povijesni elementi, a kao poučno-zabavni listovi, kasnije i politički, HB, NHB i GH donose ne samo paremiju u pojedinačnim tekstovima, nego cijele popise "narodnih izreka" kao osobitost narodnoga, moralnoga, iskustvenoga, praktičnoga, poučnoga i povijesnoga izričaja.

Osim što se uvrštavaju u novinske rodove (članke, vijesti, komentare) tiskaju se i posebni podlistci (feljtoni) s brojnim objavljenim paremijama. Tako uredništvo ima posebnu rubriku pod nazivom "Listak" navodeći paremije s oskudnim objašnjenjem i najčešće bez njega. $S$ obzirom na blizinu Dalmacije i činjenicu da je u novinama bilo vijesti s toga područja, zaključuje se da su novine imale svoje dopisnike iz raznih krajeva gdje su rado i čitane. Mnogo je objavljenih paremija iz južne Dalmacije, a razlog je to posuđivanja materijala i upoznavanja čitatelja s narodnim izričajem iz susjednoga područja.

$\mathrm{U}$ dva je lista dan poseban popis paremija, a one se redovito objavljuju u svim listovima. Tako dva broja NHB-a (NHB, 1884.: II/3/2) i (NHB, 1885.: II/1/1) daju poveći popis paremija s organskim (pučkim) obilježjima i istaknutim moralno-edukativnim karakterom. GH daje popis poslovica koje je "sabrao Frano Radić kao poslovice bodulanaca na Braču"28 (GH, 1885.: II/48/2). Na istom se mjestu daje

II., br. 38-51; 1886., god. III., br. 1-52; 1887., god. IV., br. 1-48; 1888., god. V., br. 1-50; 1889., god. VI., br. 1-50; 1890., god. VII., br. 1-66; 1891., god. VIII., br. 1-87; 1892., god. IX., br. 1-82; 1894., god. XI., br. 1-92; 1895., god. XII., br. 1-87 - političko-informativni list. HB je tjednik, sadržajno je ograničen samo na zabavu i pouku, donosi povijesne članke, prijevode književnoumjetničkih tekstova i romana (npr. Victor Hugo, Jadnici), domaće i strane vijesti, narodne pjesme i izreke, prevedene zabavno-poučne tekstove njemačkih, talijanskih i drugih listova. NHB izlazi u većem formatu, latinicom i ćirilicom (bez natpisa na ćirilici), sadržajno proširen hercegovačkim i dalmatinskim narodnim običajima. GH je informativno-politički list u kojem se objavljuju uza sve navedeno i komentari i osvrti.

28 Jedna od napomena uredništva za navedene paremije iz GH-a je i ova: "Sabiraoc je bio poslao sedamdeset ovih poslovica uredništvu pokojnoga "Vuka" koje nehće (sic!) udostojiti se da jih primi za svoj časopis kao nevalajnu staru ropotariju vanka mode, obazirući se do zadnjega časa sučijava života svoga, da bi mu posalo štogod nova i mudrijega nego li je pučka mudrost sadržana 
Irina Budimir - Paremiološka građa hercegovačke hrvatske periodike...

i fonološko objašnjenje za čitanje poslovica iz Dalmacije (dvoglasi $\mathrm{ou}>\mathrm{u}$; uo $>0$; ar $>\mathrm{r}$; ili fonem /o/>a). ${ }^{29}$ Većina paremija dolazi iz narodne predaje, latinskoga jezika i biblijskih tekstova.

Iz svih godišta izdvojeno je za ovu raščlambu oko 180 paremija. Listovi bilježe i latinske, talijanske i francuske paremiološke vrste. ${ }^{30}$ Što je zanimanje za objavljivanjem raznolika sadržaja, posebno političkoga, iz različitih stranih novinskih izvora bilo veće, to je utjecaj tih stranih jezičnih elemenata bio prisutniji.

Većina tekstova koje potpisuje urednik pod pseudonimom M (misli se na Milićevića) sadrži latinske izreke, ali i latinski prijevod biblijsko-liturgijskih sentencija i uzrečica. Takvi oblici obično nisu pisani u obliku kakva danas poznajemo, ili im je ispušten jedan strukturni dio (prijedlog, množinski oblik ili cijeli rečenični dio), ili su transfonemizirani i prilagođeni organskome izgovoru.

\begin{tabular}{|l|l|}
\hline $\begin{array}{l}\text { Latinska paremiološka vrsta u } \\
\text { tiskovinama }\end{array}$ & Izvorni oblik \\
\hline $\begin{array}{l}\text { fiat justica pereat mundus } \\
(\mathrm{NHB}, 1885 .: \mathrm{II} / 30 / 2)\end{array}$ & fiat iustitia et péreat mundus \\
'neka se vrši pravda pa makar \\
propao svijet'
\end{tabular}

rečenijem poslovicama. No mi ih neiznašamo kao klasične, već kao narodne, a time još više, da čitatelji upoznaju kako se gdje služi da jednom te istom poslovicom" (GH, 1885.: II/28/3).

29 Primjeri se za hrvatsku paremiju navode izvorno, bez ikakvih grafijskih preinaka. Jezik hercegovačke hrvatske periodike nije opisivan. Moguća tiskarska pogrješka ili nedovršena riječ u paremiji označena je oznakom (sic!), tj. "upravo tako piše". Urednici ili sami prikupljivači u svrhu boljega razumijevanja u nekim paremijama navode kontekstualne sinonime npr.: ča ćaća (otac) boćo (rasiplje) - sve kuća ploćo (GH, 1885.: II/48/2) ko ti je svuoj, daje (dalje) ga se stuoj (GH, 1885.: II/48/2).

$30 \mathrm{U}$ ovom se radu taj korpus nije posebno raščlanjivao, ali je nesumnjivo njegova čestotnost bila velika. Uz paremiju, najčešći oblici su: izreke, krilatice i uzrečice. 


\begin{tabular}{|c|c|}
\hline \begin{tabular}{|l|} 
onores mutant mores $(\mathrm{GH}$, \\
1888.: V/41/2) \\
'časti mijenjaju običaje' \\
\end{tabular} & honores mutant mores \\
\hline $\begin{array}{l}\text { tempora matantur }(\mathrm{GH}, 1892 .: \\
\mathrm{IX} / 50 / 2)\end{array}$ & $\begin{array}{l}\text { témpora mutántur et nos } \\
\text { mutámur in illis }\end{array}$ \\
\hline $\begin{array}{l}\text { 'vremena se mijenjaju i mi se mi- } \\
\text { jenjamo s njima' }\end{array}$ & \\
\hline $\begin{array}{l}\text { modus opredandi (GH, 1887.: } \\
\text { IV/29/2) } \\
\text { 'način djelovanja' }\end{array}$ & modus operandi \\
\hline $\begin{array}{l}\text { videant consules }(\mathrm{GH}, 1892 .: \\
\mathrm{IX} / 54 / 2)\end{array}$ & $\begin{array}{l}\text { vídeanat cónsules, ne quid de- } \\
\text { triménti res pública cápiat }\end{array}$ \\
\hline 'neka pripaze konzuli' & $\begin{array}{l}\text { 'neka se konzuli pobrinu da drža- } \\
\text { va ne pretrpi kakvu štetu' }\end{array}$ \\
\hline \begin{tabular}{|l} 
quando Marus pasca dabit, \\
todus mundus vaeclamabit \\
$(\mathrm{GH}, 1885 . \mathrm{I} / 44 / 3)$
\end{tabular} & $\begin{array}{l}\text { quando Marcus pascha dabit, } \\
\text { totus mundus vae clamabit. }\end{array}$ \\
\hline $\begin{array}{l}\text { 'kada Maro daje pašu, cijeli svijet } \\
\text { će vikati ajme' }\end{array}$ & \\
\hline $\begin{array}{l}\text { amor partiae (sic!) (NHB, 1885.: } \\
\text { II/34/2) } \\
\text { 'domoljublje' }\end{array}$ & amor patriae \\
\hline $\begin{array}{l}\text { munuds vult decipi ergo deci- } \\
\text { paatur (sic!) }(\mathrm{GH}, 1892 .: \mathrm{IX} / 33 / 1)\end{array}$ & $\begin{array}{l}\text { mundus vult décipi, ergo déci- } \\
\text { piátur }\end{array}$ \\
\hline $\begin{array}{l}\text { 'svijet želi biti prevaren, pa neka } \\
\text { bude' }\end{array}$ & \\
\hline $\begin{array}{l}\text { patries conseripti (GH, 1887.: } \\
\text { IV/29/3) } \\
\text { 'senatori' } \\
\end{array}$ & patres conscripti \\
\hline $\begin{array}{l}\text { stat pro ratione voluntas }(\mathrm{GH}, \\
\text { 1888.: V/10/3) } \\
\text { 'umjesto razloga neka bude volja' }\end{array}$ & $\begin{array}{l}\text { hoc volo, sic iúbeo, sit pro ra- } \\
\text { tióne volúntas }\end{array}$ \\
\hline
\end{tabular}


Irina Budimir - Paremiološka građa hercegovačke hrvatske periodike...

Jedan dio latinskih izreka može se pripisati biblijsko-liturgijskome stilu, npr.: ab ortu enin solis usque ad occasum ('od izlaska do zalaska sunca') (GH, 1886.: III/28/2); devoravi librum ('progutao sam knjigu') (GH, 1886.: III/12/2); per pedes apostolorum ('stopama apostola') (GH, 1887.: IV/11/2); nunc dimittis ('sad otpuštaš') (NHB, 1885.: II/31/3).

Ostale izreke, paremije i sl. dio su ustaljena jezičnog izbora pisaca raznih članaka, a posebice političkih članaka, komentara i osvrta u GH-u:

ad absurdum ('do apsurda') (GH, 1892.: IX/77/2); ad akta (sic!) ('baciti u zaborav') (GH, 1886.: III/8/1); ad multos annos ('na mnogaja ljeta') (GH, 1886.: III/45/2); ad quid ('čemu to') (GH, 1886.: III/1/1); bona fide ('u dobroj vjeri') (GH, 1887.: IV/18/2); Dixi unus ('rekoh jedan') (GH, 1892.: IX/36/2); caput et porta Croatiae ('glava i vrata Hrvatske') (GH, 1892.: IX/50/2); Christe vicisti ('Kriste, pobijedio si!') (GH, 1888.: V/18/1); do ut des ('milo za drago') (GH, 1892.: IX/32/2); et mortuus est ('mrtav je') $(\mathrm{GH}, 1888 .: \mathrm{V} / 12 / 1)$; et similia ('i slično') $(\mathrm{GH}$, 1887.: IV /27/3); et vice versa ('obrnuto; $\mathrm{u}$ drugom smjeru') (GH, 1885.: II/40/2); ex auctoritate ('po ovlasti') (GH, 1886.: III/31/2); extra Hungariam non est vita non est ita ('izvan Mađarske nema života, i ako je života nije tako') (GH, 1886.: III/9/3); horible dictu ('strašno rečeno') (GH, 1892.: IX/46/1); ibis redibis non in bello moriebis ('radit ćeš i ne ćeš umrijeti') (GH, 1886.: III/22/2); intus et foris ('iznutra i izvana') (GH, 1887.: IV/29/2); litteras baptismales ('krsni listovi') (GH, 1886.: $\mathrm{III} / 5 / 2)$; mapa mundo ('zemljopis') (GH, 1888.: V/10/2); noli me tangere ('ne diraj me') $(\mathrm{GH}, 1886 .: \mathrm{III} / 34 / 1)$; nomina sunt odiosa ('imena se ne spominju') (GH, 1895.: XII/31/1); non quis sed quid ('ne tko, nego što') (GH, 1895.: XII/31/1); pax dico vobis, frater ('mir kažem vama, brate') (GH, 1888.: V/10/3); per fas et nefas ('po dopuštenim i nedopuštenim; ne birati sredstva za cilj') (GH, 1886.: III/1/3); post tot discrimina rerum ('poslije toliko teških stvari') (GH, 1892.: IX/50/2); spirite inferale ('podzemni duhovi') (GH, 1892.: IX/15/1); stadium algidum ('hladni stadij') (GH, 1886.: III/31/3); qui perseraverit usque in finem salvus erit ('tko ustraje do kraja, bit će spašen') (GH, 1887.: IV/35/1); redde rationem ('položiti račun') (GH, 1886.: III/24/1); salus reipublicae, lex esto ('opće dobro neka bude zakon') (NHB, 1885.: II/29/1); sic est in fatis ('takva je sudbina, tako je suđeno') (GH, 1888.: $\mathrm{V} / 9 / 2)$; sine quare ('zašto ne') (GH, 1888.: V/1/1); status quo ante ('stanje kao prije') (GH, 1885.: II/41/1); tabula rasa ('bez znanja') (GH, 1886.: III/1/1); urbi et orbi ('gradu i svijetu') (NHB, 1885.: II/30/2); volens-nolens ('htijući-nehtijući') (NHB, 1885.: II/30/2). 
U svim listovima autori tekstova koriste i talijanske izreke i paremije. Utjecaj je to samoga autora, njegove izobrazbe, stila pisanja, ali u najvećoj mjeri prevođenja mnogih vijesti i drugih novinskih rodova iz drugih informativnih izvora. Međutim, dosta takvih oblika ostavljaju neprevedenim, npr.: ala toskanese ('pod toskansku') (GH, 1892.: IX/4/3); becco contento ('imati štetu i ne mariti za nju') (GH, 1886.: III/17/2); che Dio se lo abbia in gloria ('da ga Bog uzme u svoju slavu') (GH, 1886.: III/38/3); il volere è potere ('volja je moć') (NHB, 1885.: II/33/2); la dolce favella del si (sic!) ('slatki govor potvrđivanja') (GH, 1885.: II/39/2); megli (sic!) anche tardi, che mai ('bolje i kasno nego nikad') (GH, 1892.: IX/24/2); nobile e genereso ('plemenit i velikodušan') (GH, 1892.: IX/78/2).

U tiskovinama se bilježe francuski izrazi i paremije. Napisani su često bez naglasaka što je zasigurno bio veći tehnički, tiskarski problem, a neki su diftonzi jednostavno fonetizirani što se opet može pripisati subjektivnosti pisaca. Takve su sintagme i izrazi npr.:

\begin{tabular}{|l|l|}
\hline $\begin{array}{l}\text { Francuska paremiološka vrsta u tisko- } \\
\text { vinama }\end{array}$ & Izvorni oblik \\
\hline $\begin{array}{l}\text { fait accompli }(\mathrm{GH}, 1885 .: \mathrm{II} / 40 / 1) \\
\text { 'savršen čin' }\end{array}$ & \\
\hline $\begin{array}{l}\text { curage chretien }(\mathrm{GH}, 1886 .: \mathrm{III} / 12 / 2) \\
\text { 'kršćanska hrabrost' }\end{array}$ & courage chrétien \\
\hline $\begin{array}{l}\text { en verite }(\mathrm{GH}, 1888 .: \mathrm{V} / 8 / 2) \\
\text { 'zbilja, zapravo' }\end{array}$ & en verité \\
\hline $\begin{array}{l}\text { en visière auverte }(\mathrm{GH}, 1892 .: \mathrm{IX} / 51 / 2) \\
\text { 'otvorenog vizira; otvoreno' }\end{array}$ & on visière ouverte \\
\hline $\begin{array}{l}\text { per ecelenticum }(\mathrm{GH}, 1885 .: \mathrm{I} / 42 / 3) \\
\text { 'naročito, osobito, } \mathrm{u} \text { prvome redu' }\end{array}$ & par excellence \\
\hline $\begin{array}{l}\text { passable }(\mathrm{GH}, 1888 .: \mathrm{V} / 8 / 2) \\
\text { 'prihvatlivo, može proći' }\end{array}$ & \\
\hline $\begin{array}{l}\text { noblesse oblige }(\mathrm{GH}, 1888 .: \mathrm{V} / 9 / 1) \\
\text { 'plemstvo obvezuje' }\end{array}$ & \\
\hline $\begin{array}{l}\text { tout est perdu sauve l honneur }(\mathrm{GH}, \\
1888 .: \text { V/8/2) } \\
\text { 'sve je izgubljeno osim časti' }\end{array}$ & $\begin{array}{l}\text { tout est perdu sauf } \\
\text { l'honneur }\end{array}$ \\
\hline $\begin{array}{l}\text { une affaire seriuse }(\mathrm{GH}, 1888 .: \mathrm{V} / 8 / 2) \\
\text { 'ozbiljna stvar' }\end{array}$ & une affaire sérieuse \\
\hline $\begin{array}{l}\text { vis-á-vis }(\mathrm{GH}, 1892 .: \mathrm{IX} / 27 / 2) \\
\text { 'naspram ili glede' }\end{array}$ & \\
\hline
\end{tabular}


Irina Budimir - Paremiološka građa hercegovačke hrvatske periodike...

\subsection{Raščlamba hrvatske paremije u hercegovačkim hrvat- skim novinama na prijelazu iz 19. u 20. stoljeće}

U nastavku rada prikaz će se strukturna i semantička raščlamba hrvatskih paremija.

\subsubsection{Strukturna raščlamba}

Jednostavna (prava ili potpuna) paremija, kako je istaknuto na početku rada, ima ustaljenu strukturu. Paremija je strukturno obično rečenica, to je obično "prava" paremija, ${ }^{31}$ i u korpusu se mogu izdvojiti: a) jednostavne rečenice, b) krnje rečenice i c) složene rečenice. $\mathrm{Za}$ veći je dio njih karakterističan obilježeni red riječi i struktura upravnoga govora. Svakako su najbrojnije strukture složene rečenice koje kao najčešći vremenski oblik imaju gnomski prezent.

\section{a) Jednostavne rečenice}

igraju mišije kolo (NHB, 1884.: II/3/2); jedan ciganin nepravi vašara (GH, 1892.: IX/12/1); ključ i balonca (kontar), spasenje donošije ( $\mathrm{GH}, 1885 .: \mathrm{II} / 48 / 2)$; kućne riči voda opiro $(\mathrm{GH}, 1885 .: \mathrm{II} / 48 / 2)$; lako ti je tujuom rukom zmaju lovit $(\mathrm{GH}, 1885 .: \mathrm{II} / 48 / 2)$; netiče mu skut g....e (sic!) (GH, 1885.: II/48/2); ni potriba svakomu vitru jidra otvarat (GH, 1885.: II/48/2); nije bog (sic!) dao kozi dug rep (GH, 1892.: IX/12/1); sita Puja za buhu nemori (GH, 1885.: II/48/2); smarti i guostu vajô se uvik nodat $(\mathrm{GH}, 1885 .: \mathrm{I} / 48 / 2)$; starijo sestro, sve druge udaje $(\mathrm{GH}, 1885$.: $\mathrm{II} / 48 / 2)$; svaka ptica svojim glasom pjeva $(\mathrm{GH}$, 1895.: $\mathrm{XII} / 53 / 3)$; svakomu je svoje dite drago (GH, 1885.: II/48/2); tuj kruh imo devet kuor (GH, 1885.: II/48/2); u zla muža žena ružna (GH, 1885.: II/48/2); urkovca glava neboli (GH, 1885.: II/48/2); žena mužu karpa prilipljena (GH, 1885.: II/48/2).

\section{b) Krnje rečenice}

boje divuojka čujena, nego vigjena (GH, 1885.: II/48/2); ča ni lipo vidit, ni lipo ni jubit (GH, 1885.: $\mathrm{II} / 48 / 2)$; ko dite za ruku, matijer za srce (GH, 1885.: II/48/2); nečini načina neg začina Druge vele: nečini začin neg način (GH, 1885.: II/48/2); ni ti doma, do doma

31 P. Mikić - D. ŠKara, Kontrastivni rječnik poslovica, str. X. 
(GH, 1885.: II/48/2); pusti dici na voju, sebi tugu i nevoju (GH, 1885.: $\mathrm{II} / 48 / 2)$; rič iz just, kom iz ruk (GH, 1885.: II/48/2); svaka bi usta izila (GH, 1885.: II/48/2); svaka ptica svome jatu - a sestrica svuome bratu (GH, 1885.: II/48/2); svaki zojom, vroćom (GH, 1885.: II/48/2); u Tuije (sic!) krave, boje vime (GH, 1885.: II/48/2).

\section{c) Složene rečenice}

boja je bab liti, nego divuojka zimi (GH, 1885.: II/48/2); boje da te kuga pomete - nego da te morčano sunce upeče (GH, 1885.: II/48/2); boje jedanput zarumenit, nego stuo problidit (GH, 1885.: $\mathrm{II} / 48 / 2)$; boje no se, nego u se (GH, 1885.: II/48/2); boje pošteno umrit, nego sramotno živit (GH, 1885.: II/48/2); boje se je gorijem mužu nazvat žena - nego bojijem bratu sestra $(\mathrm{GH}, 1885 .: \mathrm{II} / 48 / 2)$; boje svoj lino, nego tuje plašno (GH, 1885.: II/48/2); boug sriće dili - a princip (dužd mletački) baškot (GH, 1885.: II/48/2); ča gluh nečuje, vuon se domišljo (GH, 1885.: II/48/2); da je strog ruke kako oči, nebi se nikad ništa učinilo (GH, 1885.: II/48/2); dobro se je i kašnje nodat, kad se imo od čega (GH, 1885.: II/48/2); guost i smart nezno se kad će kući prit (GH, 1885.: II/48/2); jedna nehtila, druga želila, treća Boga molila (GH, 1885.: II/48/2); kad čovika smart dostigne - tad od njega svak pobigne (GH, 1885.: II/48/2); kad sliepac sliepca vodi, oba se u jamu sunovrate (GH, 1892.: IX/43/6); ko klapje (kuca), otvoreno mu je (GH, 1885.: II/48/2); ko na dilu ni, njemu dila ni (GH, 1885.: II/48/2); ko ni lin, ni ni glodan (GH, 1885.: II/48/2); ko puno dili, brzo prosi (GH, 1885.: II/48/2); ko robu šćiedi, nega roba riješi $(\mathrm{GH}$, 1885.: II/48/2); ko s djavlom tsadi (sic!) tikve, o glavu mu pucaju (GH, 1892.: IX/31/3); ko se tužim, uon se ruži (GH, 1885.: II/48/2); ko storo nekarpi, novo nedere (GH, 1885.: II/48/2); ko susidu ljudi, ni postoulce dere nit se daleko trudi (GH, 1885.: II/48/2); luda lisica hvata se za nogu, a pametna za gubicu (GH, 1886.: III/28/3); mudri jidu, a ludi ploćoju (GH, 1885.: II/48/2); muž maruje na bolestnu ženu - ko brat na ubogu sestru (GH, 1885.: II/48/2); najgora je ptica koja svoje gnjezdo gadi (GH, 1892.: IX/51/3); negledo se čovik čela nego kolač na stolu (GH, 1885.: II/48/2); nemože se križ nosit i Boga molit (GH, 1885.: II/48/2); neznô tovor, ča je petrusimul (GH, 1885.: II/48/2); neznoš za štijednju, dok nepočmeš svojuom suolju solit (GH, 1885.: II/48/2); ni maška kriva, da je gospodarica lina (GH, 1885.: II/48/2); ni pšenica bez kukolja, ni selo brez prikova (GH, 1892.: IX/10/2); proklijeta svaka g...(sic!) koja nebi izila (GH, 1885.: II/48/2); ruka ruku mije, a obroz obedvije (GH, 1885.: II/48/2); svak 
Irina Budimir - Paremiološka građa hercegovačke hrvatske periodike...

zao ča je komu u svojuoj kući (GH, 1885.: II/48/2); tko je srećean (sic!) i sreća mu pjeva (GH, 1887.: IV/18/3); tko je nesreća i sreća mu plaće (sic!) (GH, 1887.: IV/18/3); uditeta malo (sic!) ruka, a velo oko (GH, 1885.: II/48/2); u kući plačni guost - vonka veseli guost $(\mathrm{GH}$, 1885.: II/48/2); u svakuoj vali svuoha vitra - u svakuoj kući svuoga dima (GH, 1885.: II/48/2); vojô se bojat i pandila divuojke (služkinje), ča za vrota visi (GH, 1885.: II/48/2).

Paremiološko stilsko obilježje je rima. Izrazito starije obilježje je obilježen red riječi (glagol na kraju rečenice kao sintaktički kalk iz latinskoga ili njemačkoga jezika) i pojavljuju se strukture upravnoga govora. Iz korpusa hercegovačkih hrvatskih novina na prijelazu iz 19. u 20. stoljeće izdvajamo strukture kojima je svojstvena:

\section{- Uvjetovanost rimom}

bložijeno puno ručic - a proklijeto puno g... (sic!) (GH, 1885.: II/48/2)

bogastvo pokrije rogastvo ( $\mathrm{GH}, 1885 .: \mathrm{II} / 48 / 2)$

ča ćaća (otac) boćo (rasiplje) - sve kuća ploćo (GH, 1885.: II/48/2)

ći udona, susida nazvona (GH, 1885.: II/48/2)

di ni oca, ni ni luonca (GH, 1885.: II/48/2)

djevojka u broju, kao pčela u roju (NHB, 1884.: II/3/2)

dobrota se po svem svitu foli. Lipota se po parsuri vori (GH, 1885.: $\mathrm{II} / 48 / 2)$

izbirač našo otirač (GH, 1895.: XII/56/1)

justa su molo rapica - a duboko jamica (GH, 1885.: II/48/2)

ko nosi neprosi (GH, 1885.: II/48/2)

ko se zlo uparti - teško njemu do smarti (GH, 1885.: II/48/2)

ko ti je svuoj, daje (dalje) ga se stuoj (GH, 1885.: II/48/2)

kokot pivo, kokot progovara: - težko kući, di ni gospodara (GH, 1885.: II/48/2)

mojka bila, mojka mila (GH, 1885.: II/48/2)

plahivom trguovcu - g... (sic!) u tobuolcu (GH, 1885.: II/48/2)

sestra bratu kako grod - a brat sestri kako vrog (GH, 1885.: II/48/2) 
staro karpi, kuonce trati - staro ljubi, danke gubi (GH, 1885.: II/48/2) svaka ptica svome jatu - a sestrica svuome bratu (GH, 1885.: II/48/2) svako g... (sic!) voda opiro - p...m (sic!) ga ko (GH, 1885.: II/48/2) svako pjanica, po sebi znanica $(\mathrm{GH}, 1885 . \mathrm{II} / 48 / 2)$ tko će ukrasti koku, taj će i voku (GH, 1892.: IX/78/2) teško meni po rodu mojiemu - ako nimom u žepu svojiemu (GH, 1885.: II/48/2)

teško meni i mrkovu mom, kad ja nemam u tobolcu svom (GH, 1892.: IX/41/4)

vince gladi lice $(\mathrm{NHB}, 1884 .: \mathrm{II} / 3 / 2)$

u zla dužnika - i koza bez mlika (GH, 1885.: II/48/2)

\section{- Obilježen red riječi}

čin dici, ženi i psu tuju - dokle činiš oslužuju - kad do malo sve zabudu (zaborave) (GH, 1885.: II/48/2)

jezik tuče gdje zub boli (NHB, 1884.: II/3/2)

muž plače ženu dokle kotlijenka vre, a žena muža dokle lopiža (GH, 1885.: II/48/2)

s gorkom suzom i modrice se smoče (NHB, 1884.: II/3/2)

s početka se vidi u kojoj vodi može sir biti (NHB, 1885.: II/1/1)

zdravo meso crv nejede (NHB, 1885.: II/1/1)

- Oblik upravnoga govora

govori drača: "Netič me, nijeću te" (GH, 1885.: II/48/2)

nagovori (sic!) se: hoćeš li? Nego: evo ti! (GH, 1885.: II/48/2)

zmaja (sic!) govori: "Netič me, nijeću te" (GH, 1885.: II/48/2)

ženo, tko te bije? Jezik! (GH, 1885.: II/48/2) 
Irina Budimir - Paremiološka građa hercegovačke hrvatske periodike...

\subsubsection{Semantička raščlamba}

U ovoj semantičkoj raščlambi promatrat će se poslovice sa sadržajnoga i semantičkoga plana. Na planu sadržaja izrazit je broj paremija s paralelizmom kao jednim od najomiljenijih načina tvorbe ${ }^{32}$ paremija, a odnosi se na relaciju između pojedinih dijelova paremije. Oprječnost se odnosi na dvodijelni strukturni tip u kojem drugi dio stoji u oprjeci prema prvome dijelu. ${ }^{33}$

\section{- Paremiološki paralelizam}

Bolje A nego B, npr.

boje svoj lino, nego tuje plašno $(\mathrm{GH}, 1885 .: \mathrm{II} / 48 / 2)$; boje pošteno umrit, nego sramotno živit (GH, 1885.: II/48/2); boje divuojka čujena, nego vigjena ( $\mathrm{GH}, 1885 .: \mathrm{II} / 48 / 2)$.

Nije A zbog B, npr.

ni maška kriva, da je gospodarica lina (GH, 1885.: II/48/2)

Prvo A onda B, npr.

iz peci pa izreci (NHB, 1884.: II/3/2); izžvači pa proždri (NHB, 1884.: II/3/2)

Ako A, onda je B, npr.

ako su brzi volovi, zemlja je podieljenja (NHB, 1884.: II/3/2); ko se tužim, uon se ruži (GH, 1885.: II/48/2); pusti dici na voju, sebi tugu i nevoju (GH, 1885.: II/48/2)

Kako A, tako B, npr.

kakva izpovid tako i odriešenje (NHB, 1885.: II/1/1)

Tko čini A, čini i B, npr.

ko puno dili brzo prosi (GH, 1885.: II/48/2); da je zajam dobar ižene bi se zajimale (NHB, 1884.: $\mathrm{II} / 3 / 2)$; ča ni lipo vidit, ni lipo ni jubit (GH, 1885.: II/48/2); di ni oca, ni ni luonca (GH, 1885.: II/48/2)

32 "Njihov nastanak često slijedi logičkoj / matematičkoj liniji ('Tko kaže A, mora reci B'...) (...) Često su poslovice obilježene retoričkim svojstvima poput rime ili usporedbe (...)." H. Burger, Phraseologie, eine Einführung am Beispiel des Deutschen, str. 107.

33 P. Mikić - V. Suzanić, Biblijske poslovice u Hrvata, str. 16-17. 


\section{- Sadržajna oprječnost paremije}

ako je isti glas, nije daht (NHB, 1884.: II/3/2)

da je strog ruke kako oči, nebi se nikad ništa učinilo (GH, 1885.: II $/ 48 / 2$ )

ko ti je svuoj, daje (dalje) ga se stuoj (GH, 1885.: II/48/2)

pokora ako je kasna, nje častna (kajanje po repu) (NHB, 1885.: $\mathrm{II} / 1 / 1)$

sestra bratu kako grod - a brat sestri kako vrog $(\mathrm{GH}, 1885 .: \mathrm{II} / 48 / 2)$

teško meni po rodu mojiemu - ako nimom u žepu svojiemu (GH, 1885.: II/48/2)

Paremije se prema sadržaju mogu podijeliti na prave ili potpune i nepotpune. Ta je klasifikacija određena prema načinu "na koji se izražavaju i priopćavaju misli, zapažanja i iskustva prema kojem prave ili potpune paremije izražavaju cjelovitu misao u obliku pravila koje se koristi u svakodnevnom životu ('nije ovi svit od jedne pređe otkan, niti on samo jednu boju pokazuje'), a nepotpune paremije samo potvrđuju ili objašnjavaju neka iskustva i pri tom ne postavljaju izravno pravilo za život ('svak ima svoje breme')". 34

U kroatističkoj literaturi spominju se dvije podjele paremija s obzirom na semantičku preobliku, a bitno obilježje u određivanju značenja paremije je slikovitost. Što je slikovitost paremije izraženija, to je ona semantički manje prozirna.

Prema značenju mogu se razlikovati "poslovice koje imaju doslovno značenje i poslovice koje imaju preneseno značenje"35 ili prema stupnju slikovitosti razlikuju se: doslovne, prenesene i kombinirane (od doslovne i prenesene) paremije. Stupanj slikovitosti u doslovnim paremijama je najmanji ("tko laže, taj krade"), prenesene paremije su konkretne s izraženom metaforičnošću ("u laži su kratke noge"), a u kombiniranim je slikovitost manje transparentna s izraženom metaforičnošću ("i kazan ima uši"). ${ }^{36}$

34 Maja Opašić, "Prilog analizi paremiološkoga blaga fra Petra Bakule", u: Zbornik o Petru Bakuli, zbornik radova sa znanstvenog skupa "Opus fra Petra Bakule", Mostar, 17.-19. svibnja 2012. godine, Hrvatski studij Sveučilišta u Zagrebu, Zagreb, 2013., str. 337.

35 P. Mikić - D. ŠKara, Kontrastivni rječnik poslovica, str. XIII.

36 P. Mikić - V. Suzanić, Biblijske poslovice u Hrvata, str. 17-18. 
Irina Budimir - Paremiološka građa hercegovačke hrvatske periodike...

Paremija se može svrstati u različita značenjska polja kojima pripada prema kulturnom, socijalnom i povijesnom ili drugom kontekstu.

\section{- Prava ili potpuna paremija}

ruka ruku mije, a obroz obedvije (GH, 1885.: II/48/2); u laži su obično kratke noge $(\mathrm{GH}, 1895 . \mathrm{XII} / 1 / 1)$; od zraka se živit nedade $(\mathrm{GH}$, 1895.: XII/33/1); nije sve zlato što je žuto (GH, 1892.: IX/24/1)

\section{- Nepotpuna paremija}

bez groša, knjez neraboša (NHB, 1885.: II/1/1); jedna ruka umiva drugu (GH, 1895.: XII/53/1); po hladu da ga nepoznadu (GH, 1892.: IX/76/1); po tudjem prknu hiljade batina (NHB, 1884.: II/3/2); sve za obraz, obraz ni zašto (GH, 1895.: XII/82/3); na lanjskoj strnini kupi klas (NHB, 1885.: II/1/1); uvaj biele novce za crne dane (GH, 1892.: $\mathrm{IX} / 78 / 6)$; nekome se smrče nekome svanjiva (GH, 1892.: IX/24/3); i ako nije zlato sve što je žuto ( $\mathrm{GH}, 1892 . \mathrm{IX} / 24 / 2)$; zrno do trno pogača (GH, 1892.: IX/32/1); jedan u ploču, jedan čavao (GH, 1892.: IX/32/4).

\section{- Paremija doslovna značenja}

Značenje im se može shvatiti iz značenja sastavnih dijelova i nema poteškoća u razumijevanju značenja.

od šutnje ne boli glava (GH, 1892.: IX/55/4)

\section{- Paremija prenesena značenja}

Značenje im se ne može izravno shvatiti iz značenja sastavnih dijelova, imaju preneseno ${ }^{37}$ značenje i obično se koristi metafora.

37 "Preneseno značenje je izraženo u općim situacijama poput 'stvaratelj - proizvod', tj. 'promjeni raspoloženja'. Pri tome nije riječ o dvama značenjima tih paremija, od kojih bi samo jedno bilo frazeologizirano, nego o dvama stvarnim frazeološkim značenjima, koja pripadaju konvencionalnom značenju paremija." H. Burger, Phraseologie, eine Einführung am Beispiel des Deutschen, str. 109. 
di ni oca, ni ni luonca (GH, 1885.: $\mathrm{II} / 48 / 2)$; i duvarovi imadu svoja uha (GH, 1886.: III/17/2); i pauk mrežu plete, za prihranit se (NHB, 1884.: II/3/2); iz pred noža i janje bježi (NHB, 1884.: II/3/2); jednom šakom siplje, a drugom se češe (NHB, 1884.: II/3/2); kad je loga vruća, nije zec daleko (NHB, 1884.: II/3/2); kako se s bijalo, slabo puca (NHB, 1884.: II/3/2); kenjac pjeva, kad mu se uši zalije (NHB, 1884.: $\mathrm{II} / 3 / 2)$; što je više jaja, gušća je čorba (GH, 1892.: IX/55/4); u mutnoj se vodi kadšto vrlo čudne ribe love $(\mathrm{GH}, 1895 .: \mathrm{XII} / 77 / 2)$; zdravo meso crv nejede (NHB, 1885.: II/1/1)

\section{- Značenjska polja paremije}

Paremije su svrstane u pet značenjskih ${ }^{38}$ polja.

- Društveno značenjsko polje:

a) bogatstvo i siromaštvo

da je zajam dobar i žene bi se zajimale (NHB, 1884.: II/3/2)

gladan vodu nepije (NHB, 1884.: II/3/2)

sviećnjaci očišćeni (nema se šta napiti) (NHB, 1885.: II/1/1)

uzbačvu punu prijatelji su veseli (NHB, 1885.: II/1/1)

b) bezvlašće

igraju mišije kolo (NHB, 1884.: II/3/2); u mutnoj se vodi kadšto vrlo čudne ribe love $(\mathrm{GH}, 1895 .: \mathrm{XII} / 77 / 2)$;

c) ograničenost kretanja

damu (sic!) je drača pod nogom, a ploča nad glavom nebi mogao ni doli ni gori (NHB, 1884.: II/3/2)

d) općedruštvenost

djevojka u broju, kao pčela u roju (NHB, 1884.: II/3/2)

e) osuda

voli oru, konji zoblju, gotovo zrelo žito, gotova strnina; zvoni zvono uston se hvaća (NHB, 1885.: II/1/1)

38 Tipologija za semantička polja uzeta je prema primjeru: J. KeKez, Poslovice, zagonetke i govornički oblici, str. 65-196. 
Irina Budimir - Paremiološka građa hercegovačke hrvatske periodike...

f) opasnost

iz pred noža i janje bježi (NHB, 1884.: II/3/2)

g) prerana smrt

najgore kad svoj svomu svieću užeže (NHB, 1884.: II/3/2)

h) $\mathrm{rad} /$ nerad

bez groša, knjez neraboša (NHB, 1885.: II/1/1); i pauk mrežu plete, za prihranit se (NHB, 1884.: II/3/2); sladke rieči začine nedaj (NHB, 1885.: II/1/1)

i) sloga / nesloga

domaćeg se vuka u kući nebije (NHB, 1884.: II/3/2); gospodarevu kravu vuk nekolje (NHB, 1885.: II/1/1)

j) sličnost

mrav š mravom besjedi (NHB, 1884.: II/3/2); vrana vrani oči nevadi (NHB, 1884.: II/3/2)

k) zdravlje

jezik tuče gdje zub boli (NHB, 1884.: II/3/2); zdravo meso crv nejede (NHB, 1885.: II/1/1); zdravu i voda sladka (NHB, 1885.: II/1/1)

- Moralno značenjsko polje:

a) dobro i zlo

daj zlu što možeš, za nedat mu što nemožeš (NHB, 1884.: II/3/2)

b) kockanje

igra sa srećom ko loptom (NHB, 1885.: II/1/1)

c) gubljenje vremena

jedna prazna u drugoj ništa (NHB, 1885.: II/1/1)

d) mudrost

dvaput omjeri, a jednom pristriži (NHB, 1884.: II/3/2); iz peci pa izreci (NHB, 1884.: II/3/2); izžvači pa proždri (NHB, 1884.: II/3/2); jezik prikuj za perdu (NHB, 1884.: II/3/2)

e) nedostatak suosjećanja

po tudjem prknu hiljade batina (NHB, 1884.: II/3/2) 
f) neizlaznost

došla su kola do rivine (NHB, 1884.: II/3/2)

g) pohlepa

pohlepan za ribom $\boldsymbol{k}^{\prime}$ o pas za mesom (NHB, 1884.: II/3/2)

- Psihološko značenjsko polje

i mačka kralja gleda, pak ga se nepreda (NHB, 1884.: II/3/2)

i mačka se brani i od zalogaja odpadne (NHB, 1884.: II/3/2)

iza boja kopljem u bus (NHB, 1884.: II/3/2)

jednom šakom siplje, a drugom se češe (NHB, 1884.: II/3/2)

kad je loga vruća, nije zec daleko (NHB, 1884.: II/3/2)

kako se s bijalo, slabo puca (NHB, 1884.: II/3/2)

kenjac pjeva, kad mu se uši zalije (NHB, 1884.: II/3/2)

poslije boja kopljem u bus potegni komora za noge, crieva su na dvoru (NHB, 1884.: II/3/2)

- Vjersko značenjsko polje

jednu misli pop, a drugu popadija (NHB, 1885.: II/1/1)

kakva izpovid tako i odriešenje (NHB, 1885.: II/1/1)

nečovjeka mahne, griešno prodju (NHB, 1885.: II/1/1)

pokora ako jekasna (sic!) je častna (kajanje po repu) (NHB, 1885.: II/1/1)

svieća se nenosi na sakriveno mjesto ( $\mathrm{NHB}, 1885 .: \mathrm{II} / 1 / 1)$

- Filozofsko značenjsko polje

a) ljudski postupci i djela

ako je isti glas, nije daht (NHB, 1884.: II/3/2)

ako su brzi volovi, zemlja je podieljenja (NHB, 1884.: II/3/2)

bradura se gadna i grušavna gujami povija (NHB, 1885.: II/1/1) 
Irina Budimir - Paremiološka građa hercegovačke hrvatske periodike...

da je medju životinjom mir kao medju biliem hajduka nebi bilo (NHB, 1885.: II/1/1)

ili žrvanj razbij ili kučku ubij (NHB, 1884.: II/3/2)

iz vuka i lisica ruča $(\mathrm{NHB}, 1884 .: \mathrm{II} / 3 / 2)$

izbio je vranam oči $(\mathrm{NHB}, 1884 .: \mathrm{II} / 3 / 2)$

izišo je na pasje sunce (NHB, 1884.: II/3/2)

jad ga jadu pridaje (NHB, 1884.: II/3/2)

jad jada pogoni (NHB, 1884.: II/3/2)

meni sada jaje, a tebi sutra kokoš (NHB, 1885.: II/1/1)

na lanjskoj strnini kupi klas (NHB, 1885.: II/1/1)

niema gamzad apami i noktim boj zameće (NHB, 1885.: II/1/1)

nit jede, nit pije, nit mu ostaje, već sve ko u jamu (NHB, 1884.: II/3/2)

pas preda kad mačka krivo nanj gleda (NHB, 1884.: II/3/2)

pet donosi, jedan odnosi (NHB, 1884.: II/3/2)

podkovan bivolnom kožom sjaji kao kotluša (NHB, 1884.: II/3/2)

riga duša guzicu (veli se, kad se mita očitovanju) (NHB, 1884.: II/3/2)

s gorkom suzom i modrice se smoče (NHB, 1884.: II/3/2)

s početka se vidi u kojoj vodi može sir biti (NHB, 1885.: II/1/1)

svaki ima svoje orjaška diela (NHB, 1884.: II/3/2)

tko će na sviet obruč natirat? (NHB, 1884.: II/3/2)

tražeći medvida rege izgubio (NHB, 1884.: II/3/2)

u orijašah na glavi vječne noći sjede (NHB, 1884.: II/3/2)

vince gladi lice (NHB, 1884.: II/3/2)

vlastelina u gradu očekiva (NHB, 1884.: II/3/2)

b) smrt

jedna je smrt, a sto uzrokah (NHB, 1884.: II/3/2)

liekar lieči bolest, a smrt neće (NHB, 1884.: II/3/2) 


\section{Zaključak}

U starijemu je novinarsko-publicističkom funkcionalnom stilu paremija vrlo popularna i korištena je u svim tada prisutnim novinskim rodovima. Autorski članci obiluju paremiološkom građom stranoga podrijetla, osobito latinskoga. Hrvatska paremija u hercegovačkoj hrvatskoj periodici na prijelazu iz 19. u 20. stoljeće slijedi ustaljenu tradiciju prikupljanja i kontinuirana objavljivanja starijega hrvatskog paremiološkog nasljeđa u svrhu unaprjeđenja i brige za hrvatski jezik, književnost i kulturu. Strukturno paremija hrvatske javne pisane riječi na prijelazu iz 19. u 20. stoljeće zadovoljava sva paremiološka obilježja. Semantička je raščlamba pokazala da su najčešća semantička polja u koje se paremije mogu svrstati društveno, moralno i filozofsko. Svakako su to i temeljna značenja koja paremija nosi u svojoj slikovitosti i metaforičnosti. 
IRINA BUDIMIR

University of Mostar

Faculty of Humanities and

Original scientific article

Social Sciences

E-mail: irina.budimir@ff.sum.ba

Received: 28 February 2020

Accepted: 10 June 2020

\section{Paremiological materials of the Herzegovinian Croatian periodicals at the turn of the $19^{\text {th }}$ and $20^{\text {th }}$ century}

\section{Summary}

The article will show that proverbs were often applied as inevitable means of expression in the older journalist-publicist functional style and its different classes (news, review, comment, feuilleton, etc.) used at the turn of the $19^{\text {th }}$ and $20^{\text {th }}$ century. A part of not only oral folklore of one time slot, but also particularities of the contemporaneous journalist-publicist functional style which preserves cultural, language and communication heritage of one nation, were documented through their abundance in the publications of that time. Herzegovinian Croatian periodicals at the turn of the $19^{\text {th }}$ and $20^{\text {th }}$ century are abundant with paremiological materials of domestic and foreign origin. Appearance of proverbs in the journalist-publicist functional style of that time is also reflected in the importance of its usage for both the authors of the texts and their readers because it represents the expression of belief, value and norm connected to culture and relevant social values. Croatian proverb in the first Herzegovinian periodical in Croatian language follows the well-established tradition of collecting and continuous publishing of the older Croatian paremiological heritage with the purpose of improvement and care of Croatian language, literature and culture. Structurally, proverb of the Croatian publicly written word at the turn of the $19^{\text {th }}$ and $20^{\text {th }}$ century satisfies all paremiological features, and paremiological forms of the foreign origin are shown by the languages in that time most often used in the public Herzegovinian and wider space.

Keywords: proverb; journalist-publicist functional style; older Herzegovinian Croatian periodical; structural and semantic analysis. 